Vol. VII, Fasc. 1 e 2 , p. $87-90$.

\title{
VALLICULA MULTIFORMIS Rankin, 1956, FROM BRAZIL
}

(Received 19-9-957)

Eveline du Bois-Reymond Marcus

(Caixa postal 6994, S. Paulo)

(with one plate)

A Ctenophore preliminarily classified as a Coeloplana was found in Floridan waters (Smith 1945), but it was not described. Some years later (1951) Rankin announced the discovery of a Platyctenid Ctenophore which she described (1956) as the type of the new genus Vallicula, intermediate between Coeloplana Kowalevsky, 1880, and Lyrocteis Komai, 1941 (see id. 1942). Among the more than a dozen species of Coeloplana $C$. sophiae Dawydoff (1938, p. 146) from the coast of Annam has oral grooves extending from the mouth to the openings of the tentacle sheaths as Vallicula multiformis Rankin.

On the coast of São Paulo, at Ilhabela, formerly Villa Bella, Lat. $23^{\circ} 49^{\prime}$ S. Long. $45^{\circ} 27^{\prime} \mathrm{W}$. and about $60 \mathrm{~km}$ farther east, near Ubatuba, my husband and I found a total of six specimens of Vallicula multiformis in September 1951 and 1956, and March 1957. This occurrence is by no means surprising, because the fauna of our upper littoral shows intimate relations with that of the West Indies in many Classes (Ekman 1935, p. 73).

Searching for Polyclads and Opisthobranchs we found the Ctenophores under stones and among algae, chiefly Padina and Sargassum, together with Hydroids, Bugula, and Synaptula. In the laboratory dishes the Ctenophores came to the surface, adhering to it with their ventral face like Coeloplana (Abbott 1907, p. 46). After being observed alive the animals were preserved with hot "susa", not anesthetized. On purpose to complete Rankin's description with regard to gonads two of the largest animals were sectioned, but no gonads were developed.

My animals were 6-7/5-5,5 $\mathrm{mm}$ when extended. They are hyaline with brown spots and white dots, the latter probably the clear type of the epidermal gland cells. The pigment cells are specially numerous around the aboral sense organ (Fig. 2) and are preserved in the sections, 
where they were found among the connective tissue and muscle cells underlying the epidermis as in Coeloplana (ibid., p. 51).

The locomotion over the substratum, Rankin's gliding and creeping, is slow. The tentacles are extruded in an explosive manner as in Rankin's animals and contrary to the Cydippida whose tentacles drop slowly out of the sheaths like a liquid more viscous than water (Krumbach 1925, p. 964). As the muscles of the tentacles in Vallicula are longitudinal fibres (Fig. 5, 6), they certainly function as retractors, not as protractors. While in Coeloplana the tentacles are expelled rapidly and withdrawn slowly (Abbott, p. 40), both processes are rapid in Vallicula.

In Coeloplana and Vallicula the tentacular branchlets may be contracted and extended singly (Abbott, p. 56; Rankin, p. 58). Circular muscles as described of Coeloplana mitsukurii (Abbott, t. f. 38) were not obvious in my transverse sections of the filaments (Fig. 6). In my opinion the layer $(k)$ between the central strand and the four columns of longitudinal muscles $(\mathrm{m})$ consists of connective tissue, not of muscles. A thick ring between these columns and the colloblasts $(x)$, Abbott's "outer layer of circular muscle", is not developed. The cross sections of the tentacular filaments of Coeloplana bocki (Komai 1922, t. 4 f. 10) or of Lyrocteis imperatoris (id. 1942, text-fig. 7) are quite different from that of Vallicula.

The tentacle sheath is thin-walled, but near its opening provided with muscle fibres on the aboral wall. The contraction of theses muscles and of those of the body probably effects the ejection of the tentacles.

The thick walls of the spherical chambers (Fig. 4, s) which lie near the tentacle sheaths consist of an outer layer of mother cells of colloblasts $(z)$ and the inner epithelium of the gastrovascular system $(d)$. As expansions of this system, according to Rankin (p. 62) of the sub-tentacular adradial canals, the spherical chambers have the same lining as the canals $(g)$, vacuolated cells containing food particles and low, ciliated cells which produce the current. The latter occupy the aboral part of the spherical chamber which extends into one of the probably respiratory papillae $(p)$, while the alimentary cells underlie the formative layer of the colloblasts. The function of the chambers as brood pouches, which is likely as Rankin found embryos in them, is evidently facilitated by their respiratory and digestive activity.

The aboral papillae (Rankin, p. 62-63) of the Brazilian specimens are either small and numerous or four to six big ones on each half (Fig. 2) as in the Jamaican material. The papillae are disposed over the canals which enter them with diverticula. The aboral epidermis is distended by these processes and thin. Besides the conical and lobed papillae drawn here stages of different shape (Rankin) occur.

Separate areae with ciliated and with vacuolated epithelium (terminology of Komai 1922 , p. $28 ; 1942$, p. 17) appear in the canals of the gastrovascular system with exception of the so-called excretory canals. These are lined with the same narrow ciliated cells that coat the infundibulum from which they go out. Here the ciliated cells are higher 
than those of the gastrovascular canals. In the latter the cells moving the gastrovascular current are aboral and oral, the digestive cells $(d)$ lateral. This disposition is distinct in the peripheral branches. Anastomoses and ramifications in the more central parts of the system obscure this topography.

The pharyngeal epithelium consists of numerous gland cells of very large size and some ciliated cells. The pharynx is completely retracted and the mouth almost closed in my sectioned animals. The difference between the wall of the pharynx and the ventral epidermis with its much fewer glands is distinct.

My animals had fed upon Crustacea among which Amphipoda and Copepoda could be identified. One had a $3 \mathrm{~mm}$ long leg of a Crustacean in its pharynx. The striated muscle fibres of the prey were seen within the vacuolated cells of the gastrovascular canals.

\section{R E S U M O}

O Ctenóforo Vallicula multiformis Rankin, 1956, da Ordem Platyctenida, descrito da ilha de Jamáica, foi encontrado na costa de São Paulo, no litoral superior de Tihabela e perto de Ubatuba.

\section{REF E R E N C S}

ABBOTT, J, F., - 1907. The morphology of Coeloplana. Zool. Jahrb. Anat. v. 24 , p. $41-70$ t. 8-10. Jena.

DAWYDOFF, C., - 1938. Les Coeloplanides Indochinoises. Arch. Zool. expér. génér. v. 80 (1938-39) fase. 2, p. 125-162 t. 1. Paris.

EKMAN, S., - 1935. Tiergeographie des Meeres. XII + 542 p. Leipzig (Akad. Verlagsges.).

KOMAI, T., - 1922. Studies on two aberrant Ctenophores, Coeloplana and Gastrodes. 122 p. 9 t. Kyoto (Published by the author).

- 1942. The structure and development of the sessile Ctenophore Lyrocteis imperatoris Komai. Mem. Coll. Sei. Kyoto Imp. Univ. Ser. B, v. 17, n. ${ }^{9}$, art. 1, p. 1-36 t. 1-3. Kyoto.

KRUMBACH, TH., - 1925. Acnidaria - Collaria - Greifzellentiere. W. Kükenthal und Th. Krumbach, Handb. Zool. v. 1, p. 902-995. Berlin und Leipzig (W. de Gruyter).

RANKIN, J. J., - 1951. A new Platyctenid from Jamaica. Nature v. 168, p. 1047. London.

- 1956. The structure and biology of Vallicula multiformis, gen. et sp. nov., a Platyctenid Ctenophore. Journ. Linn. Soc. Zool. v. 43, n. ${ }^{\circ}$ 289, p. 55-71 t. 2-3. London.

SMITH, F. G. WALTON - 1945. The discovery of Coeloplana on American shores. Science n. ser. v. 101, n. ${ }^{\circ} 2610$, p. 17. Lancaster, Pa. 
Vallicula multiformis Rankin

Fig. 1 - Aspect of living animal.

Fig. 2 - Side view of same.

Fig. 3 - Diagram of gastrovaseular system in aboral view.

Fig. 4 - Sagittal section at level of tentacle base.

Fig. 5 - Transverse section of tentacle,

Fig. 6 - Same of tentacle filament.

$c$ - pharynx. $d$ - vacuolated epithelium. $g$ - gastrovascular canals. $i-$ tentacle. $j$ - tentacle filament. $k-$ connective tissue. $m-$ muscle fibres. o - aboral sense organ. $p$ - papilla. $s$ - spherical chamber. $t$ - tentacle sheath. $x$ - colloblasts. $z$ - formative layer of colloblasts. 
E. d. B.-R. MARCUs - Vallicula multiformis Rankin 1956, . .

PLATE I
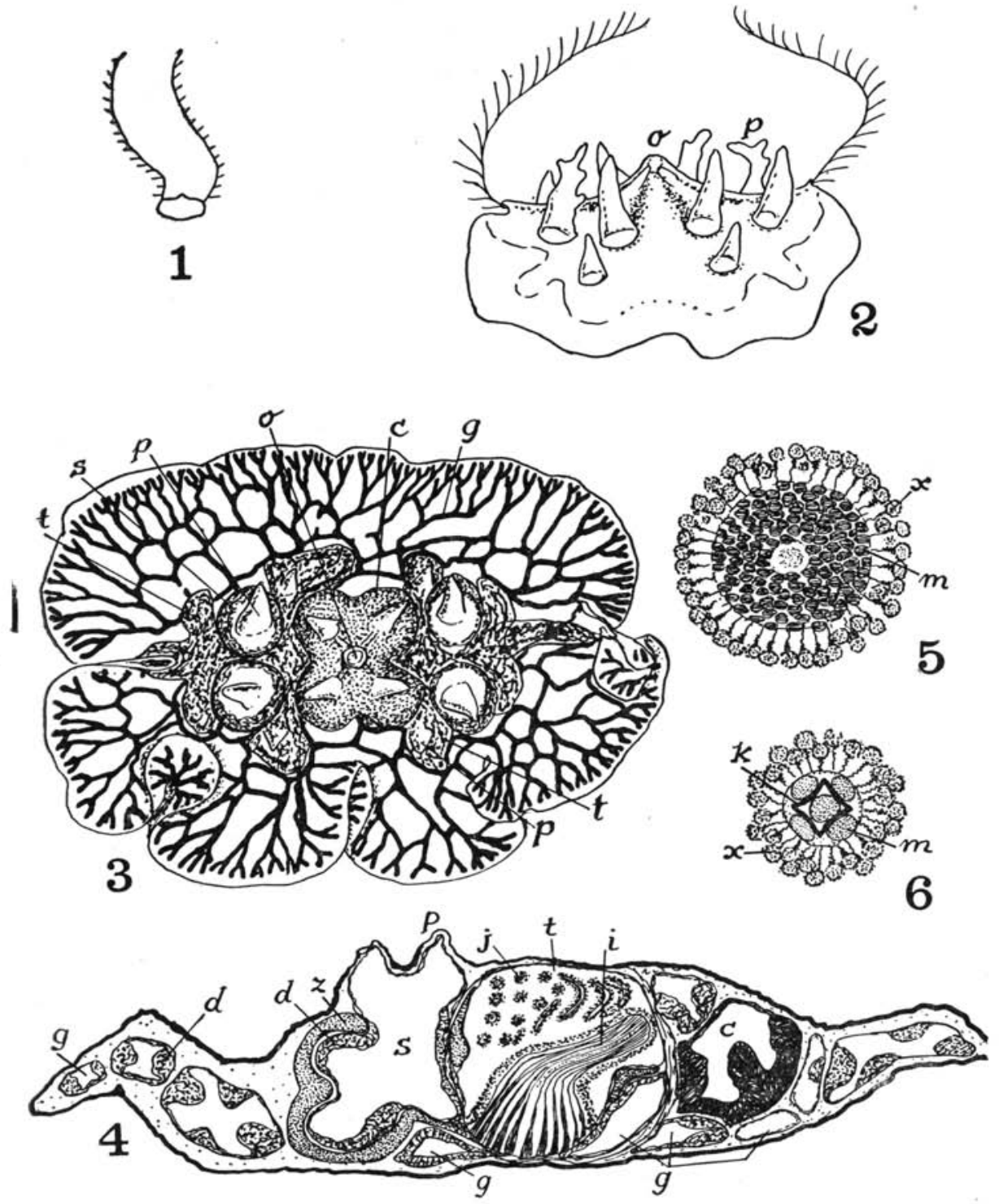